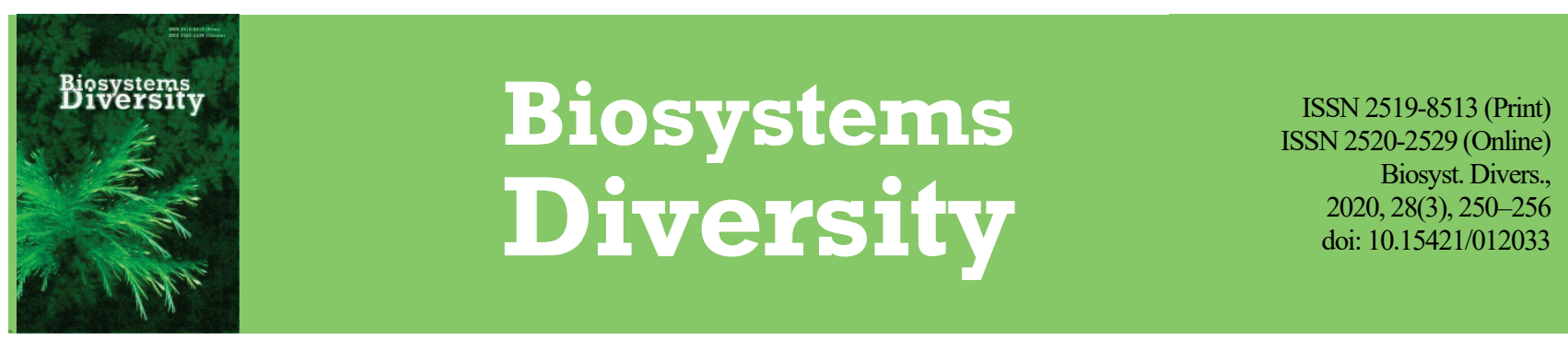

\title{
Local industrial pollution induces astrocyte cytoskeleton rearrangement in the dice snake brain: GFAP as a biomarker
}

\author{
V. Y. Gasso*, A. N. Hahut*, S. V. Yermolenko*, I. A. Hasso*, C. A. Agca**, \\ E. V. Sukharenko**,***, V. S. Nedzvetsky*,** \\ * Oles Honchar Dnipro National University, Dnipro, Ukraine \\ **Bingöl University, Bingöl, Turkey \\ ***Kerch State Maritime Technological University, Kerch, Ukraine
}

Article info
Received 10.06 .2020
Received in revised form
17.07 .2020
Accepted 18.07 .2020

Oles Honchar Dnipro National University, Gagarin Ave., 72, Dnipro, 49010, Ukraine. Tel.: +38-097-302-56-83. E-mail:vgasso@ua.fm

Bingöl University,

Selahaddin-i Eyyubi Mah.

Üniversite Cad. No 1 ,

Bingöl, 12000, Turkey.

Tel.: +90-536-891-71-50.

E-mail:

nedzvetskvvictor@ukr.net

Kerch State Maritime

Technological University,

Ordzhonikidze Av., 82,

Kerch, 98309, Ukraine.

Tel: $+797-882-000-25$

E-mail:

helenasuhar@gmail.com
Gasso, V. Y., Hahut, A. N., Yermolenko, S. V., Hasso, I. A., Agca, C. A., Sukharenko, E. V., \& Nedzvetsky, V. S. (2020). Local industrial pollution induces astrocyte cytoskeleton rearrangement in the dice snake brain: GFAP as a biomarker. Biosystems Diversity, 28(3), 250-256. doi:10.15421/012033

The present study was designed to evaluate the responsiveness of modulation of glial fibrillary acidic protein (GFAP) content and its fragmentation in the snake brain as a biomarker of local industrial pollution of aquatic ecosystems. Despite GFAP being a well known cytoskeleton marker of astrocytes' reactivity in the brain of vertebrates, its expression in the snake brain remains insufficiently described. The GFAP expression and its fragmentation were detected using the immunoblot method in the snake brain. ROS level was determined with dichlorofluorescein diacetate fluorescence. The content of the glial fibrillary acidic protein (GFAP) of filament (cytoskeleton) and soluble (cytosol) fractions in the brain of dice snake Natrix tessellata from three ecosystems with different rates of industrial pollution were studied (two polluted and one clean control site). Characteristic increase in GFAP fragmentation was noted for the snakes from both the researched polluted sites. Significant increase in the content of the GFAP cleaved polypeptide fragments induced by industrial pollution exposure was confirmed in the snakes' brains. Meaningful GFAP fragmentation was determined in snake brain astrocytes as an increase in cleaved fragments of 47-35 kDa molecular weight for both soluble and cytoskeletal GFAP fractions. We found significant abnormality in the ratio of the GFAP soluble fraction to the cytoskeletal one in contaminant-exposed dice snakes. It should testify to significant metabolic disturbance in nerve cells of the dice snakes. Furthermore, growth of reactive oxygen species level as the main cause of oxidative stress was determined in brains of the snakes exposed to environmental toxicity. Thus, astrocyte cytoskeleton disorders are associated with pollutant-induced redox imbalance in the snake brain. Despite the limited data on glial cell biology in the reptilian brain, the observed results prove that snake astrocytes can respond to the environmental toxicity using typical astroglial response. The presented results evidence that monitoring of molecular characteristics of glial cytoskeleton in dice snakes could be used as reliable biomarker of neurotoxicity and adverse effects of industrial pollution. Further studies are required to elucidate the role of astrocyte cytoskeleton in the response against neurotoxic contaminants.

Keywords: glial fibrillary acidic protein; oxidative stress; molecular sentinel; environmental contamination; reptile.

\section{Introduction}

Nowadays, practically all ecosystems are exposed to adverse effects of toxic industrial-derived compounds. Detrimental effects are caused at various rates which depend on the number, contents and level of industrial waste. Global intensification of modern technologies is accompanied by toxic chemicals' production throughout the world that determines total and local environmental pollution. In consequence, biosystems demonstrate different responses to the effect of an ecotoxicant that could be observed throughout large geographical areas (Barker \& Tingey, 1992; Sanderfoot \& Holloway, 2017; Cantonati et al., 2020). Different toxic substances absorbed by living organisms cause primary reactions at a molecular level that later occurs at all the highest levels of a biosystem's organisation. As a rule, pronounced multiple ecotoxic effects are accompanied by different deviations of animal behaviour, population parameters and species abundance (Newman \& Clements, 2007; Peterson et al., 2017; Lieshchova et al., 2018, 2019). Ecotoxicants cause changes in mortality, reproduction, community characteristics and other parameters of biosystems at any above species level (Clements \& Rohr, 2009; Van de Perre et al., 2016; Schäfer \& Bundschuh, 2018). However, the molecular basis of ecotoxicant-initiated disturbances frequently remains unknown. Undoubtedly, biochemical processes and molecular interactions are a background of modulation at all biosystem levels including consequent alterations in populations and ecosystem structure.

To assess the environmental qualitative and quantitative parameters, modern approaches of sublethal monitoring of wildlife expand the use of different biomarkers and bioindicators. For the earliest identification of harmful impact, the biochemical and molecular markers are mostly effective as long as imbalance in molecular pathways reflects the abnormalities in a biosystem at the earliest stages. New developments in molecular biology have also allowed insight into the genetic basis for wildlife response to toxic substances (Peakall et al., 1999; Kendall, 2016).

Most regions in Ukraine, especially industrially developed ones, such as the steppe Dnieper area, are characterised by a high level of chemical pollution. Therefore, different enterprises of the industrially developed Dnipropetrovsk oblast discharged about 833 thousand tons of contaminating substances into atmospheric air in 2016. The total amount of the dumped liquid sewage averaged 243.8 million $\mathrm{m}^{3}$ in 2016 (Strilets, 2017). In Zaporizska oblast, different industrial and agricultural sources discharged 167.0 thousand tons of gaseous pollutants and 112.364 million $\mathrm{m}^{3}$ of polluted waters in 2016 (Prychynenko et al., 2017).

In the regions of high concentration of metallurgical and chemical factories like Dnipropetrovsk and Zaporizhia areas, the most dangerous risk factors are heavy metals and persistent organic pollutants (POPs) 
derived from industrial emissions. Increasing ecotoxicant concentrations can lead to irreversible disturbances in the cells of living organisms with further troubles in structure and functioning of populations and communities. The detrimental effect of environmental toxicity was demonstrated in the brain of fish exposed to a complex of urban and refinery waste pollution caused by a tanker incident (Sukharenko et al., 2008). Previous results have shown growing evidence of the successful application of neurospecific proteins for estimation of the harmful effect of heavy metal, aluminium ions and industrial pollutant mixture (Nedzvetsky et al., 2011; Novitsky et al., 2013; Sukharenko et al., 2017).

The initiation of redox imbalance and consequently oxidative stress generation are the most common abnormalities in all organisms affected by various environmental toxicants. Increased level of free radicals leads to oxidizing macromolecules including lipids, proteins and nucleic acids (Yoshikawa \& Naito, 2002). Different cell types can scavenge and neutralize free radicals with both endogenic antioxidants and antioxidant enzyme systems. However, the neural tissue cells are extremely susceptible to oxidative damage because of the poverty of endogenous antioxidant substances and feeble efficacy of antioxidant enzymes (Baxter \& Hardingham, 2016; Bolaños, 2016). Thus, various toxicants could induce neurotoxicity processes associated with oxidative stress. Moreover, combined exposure to present industrial pollutants can exert synergetic effect that multiplies a toxicity effect of many compounds (Kim et al., 2014; Tanaka \& Kawahara, 2017). Thus, the neurotoxicity phenomenon can occur in both human and animal organisms because of industrial pollution. For the last decade air-derived toxicity has attracted especial interest since this contaminant type could cause neurodegeneration and brain disease (Block \& Calderón-Garcidueñas, 2009, Lucchini et al., 2012). Practically, most of the known intoxications are followed by disorder of nervous system functioning. Taking into account that neural tissue cells are susceptible to most of the widespread environmental pollutants including metal ions, POPs and pesticides, the evaluation of expression of neurospecific proteins could be an effective tool for detection of the urgent indices of both vitality and critical damages in the neural system (Nedzvetskii et al., 2001).

The cytoskeleton proteins, reparative protein A (RPA70), transcriptional regulator nuclear factor kappa-B cells (NF-kB) and DNA damage repairing poly-(ADP-ribose)-polymerase (PARP) were reported as valid biomarkers to estimate aluminium, cadmium, mercury and copper neurotoxicity (Novitsky et al., 2013; Nedzvetsky et al., 2018; Kirici et al., 2019). The study of the effect environmental toxicity on the brain is one of the relevant and major areas of research (Legradi et al., 2018; Pereira et al., 2019; Taysi et al., 2019). Besides, brain cells are critically susceptible to most pollutants, which induce irreversible metabolic and structural changes in it (Nedzvetsky et al., 2006, Taysi et al., 2019). Thus, the central nervous system represents a potential target for any ecotoxicant impact (Nedzvetsky et al., 2006; Pereira et al., 2019).

Brain functioning closely relates to adaptive and repairing systems of neural tissue cells (Hall \& Tropepe, 2020). Brain homeostasis and neuronal viability are known to be supported by surrounding neuroglial cells. They are capable of active repairing of any brain part under influence of different disturbances and damages of the nervous system. Intermediate filaments are of special importance for construction of the astrocyte cytoskeleton and providing multiple gliospecific functions in the neural system (Peters et al., 1991). Glial fibrillary acidic protein (GFAP) is the main structural component of intermediate filaments type III, which are expressed in astrocytes of all vertebrates (Aebi et al., 1988). There is a growth of evidence that the expression of aforementioned specific astroglial protein is modulated by stressful factors of different nature, and therefore the changes found in its quantity and fragmentation can serve as molecular biomarkers of the stressful influences (Nedzvetskii et al., 2005; Nedzvetsky et al., 2011).

Previous studies have shown that GFAP functions in mammals could be similar to those in reptiles in spite of morphological variability from species to species (Kalman et al., 2001; Gasso et al., 2010, 2012). Furthermore, the astrocytes of different animal species possess common features in respect to maintaining brain homeostasis in course of the various injuries and intoxications (Nedzvetsky et al., 2006; Rai, et al., 2013; Ortega \& Olivares-Bañuelos, 2020). The permanent growing level of environmental pollution worldwide give relevance to the search and investigation of valid and reliable molecular biomarkers that are able to adequately reflect the functional state of cells and therefore a whole organism indirectly.

In Squamata reptiles (snakes and lizards), astrocytes were found to be frequent in several areas, although they nowhere predominated, and extensive GFAP-poor areas were found in some species as well. As expected, they share more common astroglial features with birds. In addition, contrary to birds and mammals, different taxonomic groups of reptiles have conspicuous differences in their glial structure. The glial structure of Squamata seems to be most advanced among reptiles (Lorincz \& Kálmán, 2015). Dice snake Natrix tessellata (Laurenti, 1768) is one of the most common reptile species throughout its area of distribution including along the Dnieper River valley within the Steppe zone. Dice snake, as opposed to the sympatric grass snake Natrix natrix, occupies the smallscale areas within a certain water body and therefore may fully characterize the environmental conditions of the studied biotope (Bulakhov et al., 2007; Gasso, 2011). Previous research demonstrated unstable biochemical alterations in reptile blood under influence of pollution in the region (Klymenko \& Gasso, 2009; Gasso et al., 2016).

Both dynamic changes in cytoskeleton proteins and adaptive cell response in the snake brain could be probably convenient and informative testing parameters to be used for biotesting and biomonitoring purposes. Comparative analysis of characteristics of the snake glial cell cytoskeleton from ecosystems of different industrial pollution rate could manifest the harmful effect of pollution at the early stages of toxicity. Furthermore, the evaluation of glial intermediate filaments' fragmentation can reflect the progress in cell death and disturbance of neural cell functions (David et al., 1997; Smerjac et al., 2018; Stopnicki et al., 2019). Thus, the evaluation of dynamic changes in the glial cytoskeleton of the snake brain may be a powerful tool for the determination of the intensity of the detrimental effect of industrial toxicants derived from contemporary chemical and metallurgical enterprises. Despite the many reports on GFAP expression in the mammalian brain exposed to toxicant influence, the modulation of glial cytoskeleton in the snake brain has been studied poorly.

The aim of the presented study is the assessment of the expression level and industrial toxicant-induced fragmentation of brain GFAP in the dice snakes inhabiting ecosystems with different pollution burdens. The validation of GFAP expression as a cytoskeleton molecular marker in the brain of dice snake for evaluation of the detrimental effect of local environmental pollution was also aimed at.

\section{Materials and methods}

Mature individuals of the dice snake were caught in three locations along the Dnieper River in July - September of 2014-2016 (Fig. 1). The specimens were collected in the habitats adjoining Prydniprovska Thermal Power Station $\left(48.400^{\circ} \mathrm{N} 35.114^{\circ} \mathrm{E}, 6\right.$ specimens), in the ecosystem of Majorova Balka (the ravine, $48.263^{\circ} \mathrm{N} 35.169^{\circ} \mathrm{E}, 6$ specimens) and in ecosystems affected by emissions of industrial enterprises of Zaporizhia city $\left(47.886^{\circ} \mathrm{N} 35.135^{\circ} \mathrm{E}, 6\right.$ specimens). The main sources of pollution in Zaporizhia are the public joint-stock company "Zaporizhstal" steel works, Zaporizhia Titanium \& Magnesium Combine, and the merchant-coke plant PJSC "Zaporizhkoks". They released about 65 million $\mathrm{m}^{3}$ of polluted waters and up to 54 thousand tons of pollutants in the air annually (Prychynenko et al., 2017). Prydniprovska TPS discharged about 121.8 thousand $\mathrm{m}^{3}$ of polluted waters into the Dnieper River and up to 61 thousand tons of atmospheric pollutants during the year 2016 (Strilets, 2017). Prydniprovska TPS emits 65.64 tons of $\mathrm{Zn}, 52.18$ tons of Mn, 14.94 tons of $\mathrm{Pb}, 4.82$ tons of $\mathrm{Cu}, 200 \mathrm{~kg}$ of As, $100 \mathrm{~kg}$ of both $\mathrm{Cd}$ and $\mathrm{Hg}$ annually (Povorotnya, 2016). Deposited heavy metals, sulphur dioxide, nitric and carbon oxides, and burned coal cinders affect all organisms including the snake-inhabited biotopes near the TPS. As a result, the soil and water in a close vicinity of the TPS are permanently polluted with heavy metals, petrochemical products and different phosphates. The levels of some pollutants exceeded maximum permissible concentrations 56 times (Choban \& Choban, 2008; Kroik \& Patskova, 2011; Strilets, 2017). Majorova Balka is situated far away from industrial sources. It was chosen as a conventionally clean control site due to the low level of pollu- 
tant concentrations in the water, which are less than in other studied sites. The exterior morphology features of all the caught snakes were described previously (Yermolenko et al., 2016b). All the tested indices generally corresponded to the limits known for this species throughout its area of distribution. Among all the studied morphological indices, the only difference was the slightly higher percentage of bilateral asymmetry in snakes from the population close to the Prydniprovska TPS was found. Such changes are usually considered as an indicator of certain destabilization of the embryogenesis. The snakes from the polluted habitats in the Zaporizhia City did not demonstrate significant morphological differences. Differences in heart and lung relative weights were also found in the snake-inhabited ecosystems close to the Prydniprovska Thermal Power Station and the biotopes of Majorova Balka, which is taken as a control site (Yermolenko et al., 2016a).

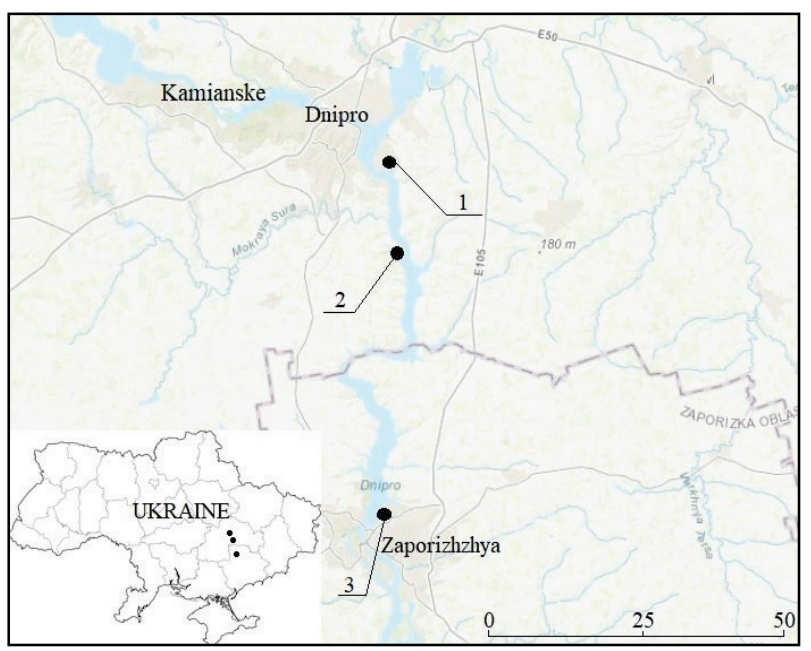

Fig. 1. Location of the studied habitats along the Dnieper River: 1 - Prydniprovska Thermal Power Station (polluted site I); 2-Majorova Balka (conventionally clean control site), 3-Zaporizhia (polluted site II)

Reactive oxygen species (ROS) were determined in the brains of the snakes according to the method described by Gupta and co-authors (Gupta et al., 2008) with a few modifications. The fresh isolated brain tissues were washed with cold phosphate buffer saline (PBS) and separately homogenized of every animal in Tris- $\mathrm{HCl}$ buffer $(50 \mathrm{mM}, \mathrm{pH}=7.4)$ on ice with ratio $1: 10 \mathrm{w} / \mathrm{v}$. The samples of every brain homogenate in volume $100 \mu \mathrm{L}$ were mixed with $1 \mathrm{~mL}$ of the aforementioned buffer and $5 \mu \mathrm{L}$ of $10 \mu \mathrm{M}$ 2',7'-dichlorofluorescein diacetate (DCFDA). After DCFDA addition, the mixtures were incubated in $37^{\circ} \mathrm{C}$ for $30 \mathrm{~min}$ on a shaker (SI-600, Jelio Tech., Korea). Then immediately fluorescence intensity was measured in all samples using a fluorescence spectrophotometer LS55 (PerkinElmer, USA) with length wave an excitation $\lambda=485 \mathrm{~nm}$ and an emission $\lambda=525 \mathrm{~nm}$

The caught snakes were described morphologically and then decapitated under soft diethyl ester narcosis for quick processing according to the rules adopted by the Bioethic Committee of Oles Honchar Dnipro National University. After decapitation, the brain was isolated, washed with PBS and cleaned from the meninges on ice. Tissue of each brain was homogenized separately in the 10-fold volume of $50 \mathrm{~mm}$ of the Tris buffer pH 7.8, containing $2 \mathrm{mM}$ ethylenediaminetetraacetate (EDTA), $1 \mathrm{mM}$ ethyleneglycoltetraacetic acid (EGTA), $1 \mathrm{mM}$ 2-mercaptoethanol, $6.5 \mu \mathrm{M}$ aprotinin, $1.5 \mu \mathrm{M}$ pepstatin $\mathrm{A}, 23 \mu \mathrm{M}$ leupeptin, $1 \mathrm{mM}$ phenylmethylsulfonyl fluoride, $1 \mu \mathrm{M}$ sodium ortho-vanadate $5 \mu \mathrm{M}$ soybean trypsin. The obtained homogenate was centrifuged in the refrigerating centrifuge for $45 \mathrm{~min}$ at $60,000 \mathrm{~g}$. The supernatant $\left(\mathrm{S}_{1}\right)$ of first after centrifugation contains soluble fraction of cytosolic proteins. To extract cytoskeleton proteins of brain tissue cells, the pellet of first centrifugation was resuspended in 4-fold volume of the same Tris buffer containing $4 \mathrm{M}$ urea as a chaotropic agent to dissociate cytoskeleton intermediate filaments. Brain tissue suspended matter was incubated for 30 min at $4{ }^{\circ} \mathrm{C}$ and centrifuge for $45 \mathrm{~min}$ at 60,000 g (Baydas et al., 2003; Kálmán \& Szabó, 2001). The supernatant $\left(\mathrm{S}_{2}\right)$ contained insoluble cytoskeleton frac- tion of brain cell proteins (Nedvetsky \& Nerush, 1999). The content of total protein was determined by Lowry method in Miller's modification (1959).

The proteins of both fractions were separated with polyacrylamide gel electrophoresis in gradient of acrylamide (5-20\%) with $0.1 \%$ sodium dodecyl sulphate (SDS-PAAG) (Laemmli, 1970). The estimation of GFAP content and polypeptide fragments composition of glial intermediate filaments was carried out with immunoblotting analysis as was described earlier (Nedzvetsky et al., 2011).

The protein bands were transferred from PAAG to nitrocellulose membrane by electroblotter (BoiRad, Germany) in Tris-glycine buffer $\mathrm{pH}$ 8.3 at $120 \mathrm{~min}$. Then the membrane was washed with saline phosphate buffer containing $0.1 \%$ Tween-20 (PBS-T) and incubated with primary anti-GFAP rabbit antibodies (1:2500, Z0334, Dako) at $4{ }^{\circ} \mathrm{C}$ overnight. After first incubation, the membrane was washed with PBS-T and incubated with HRP-conjugated secondary anti-rabbit antibodies (1:5000, R05072-500, Advansta Inc., the USA) for $1 \mathrm{~h}$ at room temperature. After washing, the blots were visualized with $0.05 \% 3.3^{\prime}$-diaminobenzidine tetrahydrochloride and $0.03 \%$ hydrogen peroxide solution. The results of immunoblotting were scanned and evaluated densitometrically using ImageJ software (Wayne Rasband, NIH, USA) (Schneider et al., 2012; Rueden et al., 2017). Relative content of GFAP was normalized to the total protein content in each respective sample.

All experiments were performed in triplicate. Statistical analysis of the data obtained was performed by use of Statistica (version 12, StatSoft Inc., USA). The results are presented as the sample mean and standard deviation (SD). The one-way ANOVA and Tukey's Honest Significant Difference Test were used to determine the differences and to confirm where the differences occurred between groups respectively.

\section{Results}

The analysis of the snakes' external morphology had not shown significant changes for populations from the polluted sites. Molecular biomarkers are considered as much more sensitive to industrial pollution.

ROS assay was carried out to detect the redox imbalance in brains of dice snake caused by environmental pollution. The results of relative ROS level in the animals' brain showed significant ROS increase in brains of snakes from both polluted sites near the Prydniprovska TPS and in Zaporizhia city by 1.6 and 1.7 times respectively (Fig. 2). Therefore, the snakes which are inhabitants of both polluted sites are characterised by high oxidative stress indices in brain tissue.

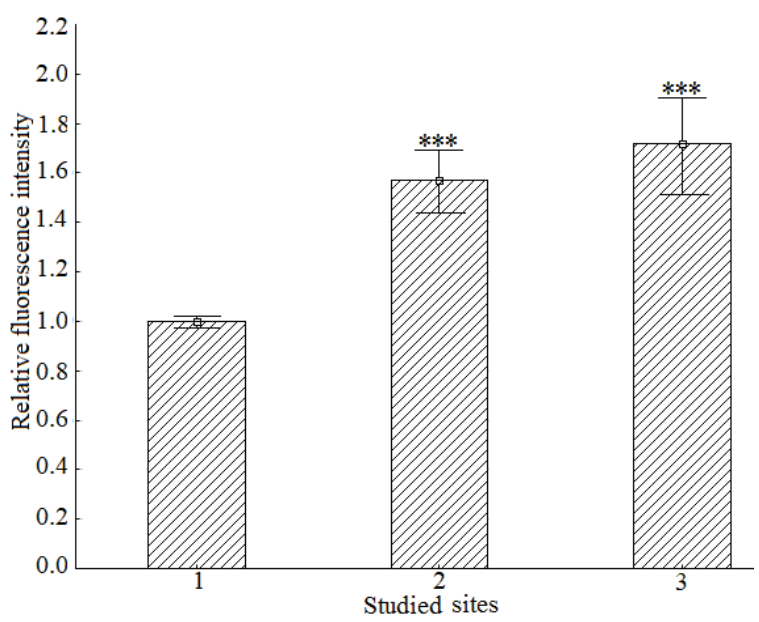

Fig. 2. Reactive oxygen species in the dice snake brain as relative fluorescence intensity normalised to control (sample mean and SD): 1 - control site (Majorova Balka, $\mathrm{n}=6$ ); 2 - polluted site I (Prydniprovska Thermal Power Station, $\mathrm{n}=6$ ); 3 - Polluted site II (Zaporizhia, $\mathrm{n}=6$ );

$$
* * *-\mathrm{P}<0.001
$$

To estimate the detrimental effect of industrial pollution on brains of snakes we carried out comparative analysis of the GFAP expression and its fragmentation in the animals' brain. The design of the present study was based on the unique feature of glial intermediate filaments to maintain 
dynamic balance between soluble cytosolic fraction and insoluble cytoskeleton or filamentous fraction in comparison with the proteins of other intermediate filament types, which form only insoluble cytoskeleton fraction. Therefore, we determined the content of both abovementioned GFAP fractions.

As compared to the reptiles caught at the control site, statistically significant higher content of GFAP was revealed in brain tissue of the snakes collected in industrially polluted areas. Significant differences in GFAP content were found for both studied fractions: insoluble cytoskeletal and soluble cytosolic ones.

The content of GFAP in filamentous cytoskeleton (insoluble) fraction (c-GFAP) detected in the brain of the snake group from the contaminated biotopes was significantly increased in comparison with the individuals selected as the control population (Fig. 3). Surprisingly, an almost similar increase in c-GFAP was observed in the brain of snakes both Prydniprovska Power Station and "Zaporizhstal" factory polluted areas. Especially, in comparison with the control, the c-GFAP amount in the snake brain from polluted sites of the Power Station and Zaporizhia city were detected as 1.7 and 2.2 times increment respectively (Fig. 4).

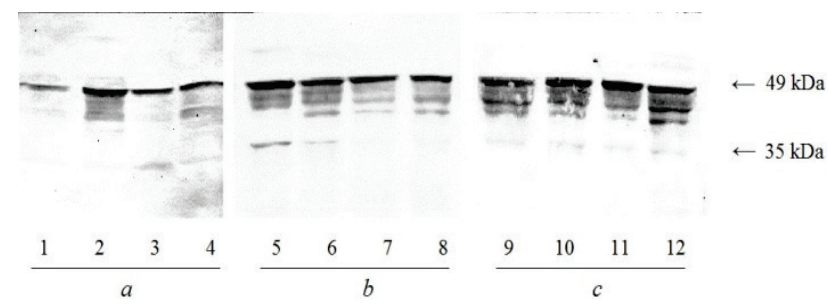

Fig. 3. Immunoblotting of cytoskeletal GFAP protein fraction of the dice snake brain: $a$-Control site (Majorova Balka); $b$ - Polluted site I (Prydniprovska Thermal Power Station); $c$-Polluted site II (Zaporizhia)

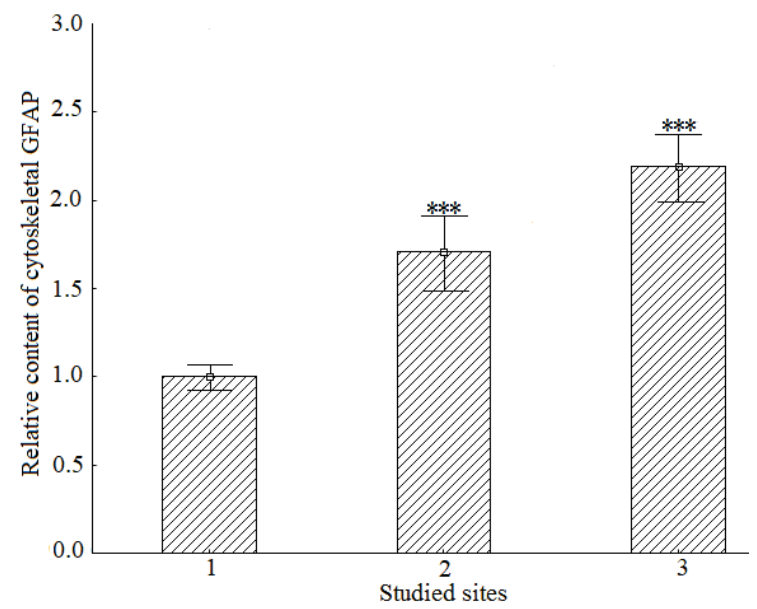

Fig. 4. Relative concentration of GFAP in cytoskeletal protein fraction of dice snake brain normalised to control (sample mean and SD): 1 - Control site (Majorova Balka, $\mathrm{n}=6$ ); 2 - Polluted site I

(Prydniprovska Thermal Power Station, $\mathrm{n}=6$ ); 3 - Polluted site II (Zaporizhia, $\mathrm{n}=6$ ); $* * *-\mathrm{P}<0.001$

Our findings have shown meaningful changes in cytosolic soluble GFAP fraction (s-GFAP) in animals exposed to environmental toxicants as compared to the chosen control group (Fig. 5). The content of s-GFAP in dice snakes caught in the vicinity of the Power Station increased by 3.8 times in comparison with a control population. A similar tendency was also found for the snakes caught in the polluted biotopes in Zaporizhia. Those snakes are characterised by 5.6 times raised s-GFAP level against the data obtained for the reptiles from the conventionally clean ecosystem (Fig. 6). The substantial significant increase of the s-GFAP form testifies to upregulated expression of intermediate filaments proteins and release of separated subunits from the filamentous structures. The astroglial reactive response is accompanied by an active reorganization of the glial cytoskeleton. We also found significant abnormality in the ratio of the GFAP soluble fraction to the cytoskeletal one in brains of contaminant-exposed dice snakes. Similar increase of this ratio was detected in both groups of snakes inhabiting the contaminated areas as compared to control (Fig. 7).

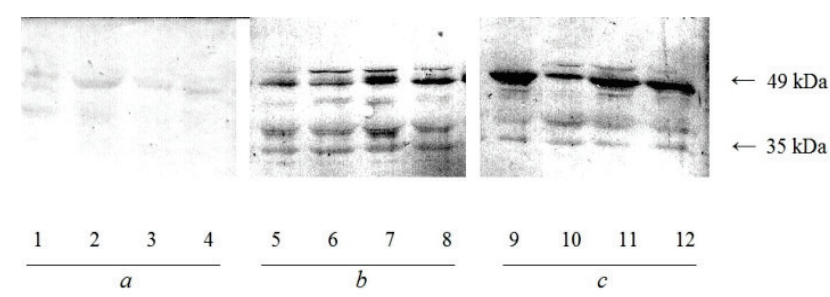

Fig. 5. Immunoblotting of soluble cytosolic GFAP protein fraction of the dice snake brain: $a$ - control site (Majorova Balka); $b$ - polluted site I (Prydniprovska Thermal Power Station); $c$ - polluted site II

(Zaporizhia)

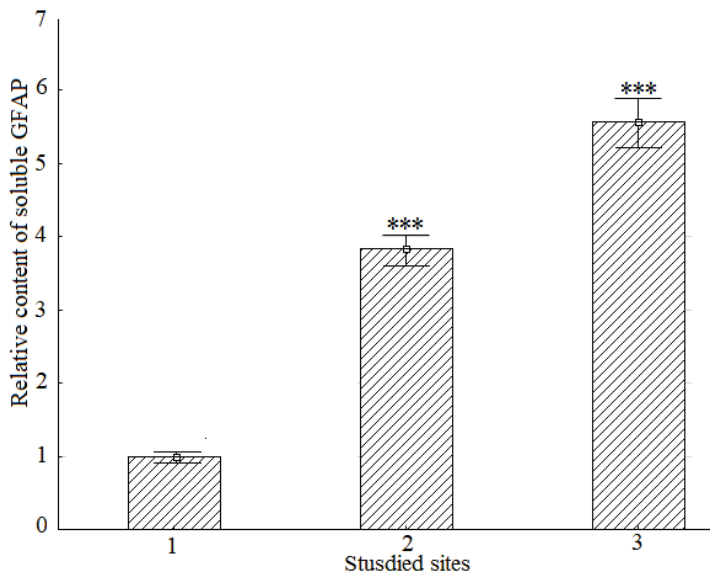

Fig. 6. Relative concentration of GFAP in soluble cytosolic protein fraction of dice snake brain normalised to control (sample mean and SD): 1 - control site (Majorova Balka, $\mathrm{n}=6$ ); 2 - polluted site I (Prydniprovska Thermal Power Station, $n=6$ ); 3 - polluted site II (Zaporizhia, $n=6$ );

$$
* * *-\mathrm{P}<0.001
$$

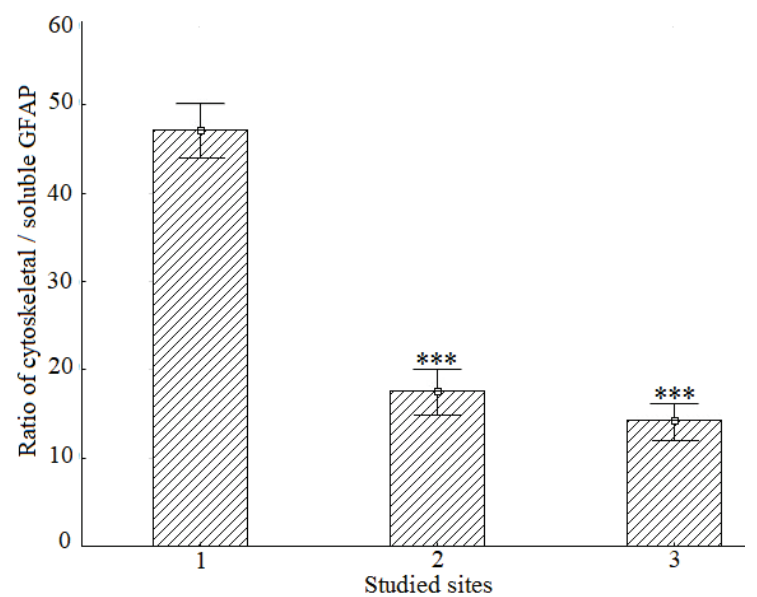

Fig. 7. The ratio of cytoskeletal and soluble GFAP content fractions in the dice snake brain (sample mean and SD): 1 - control site (Majorova Balka, $\mathrm{n}=6$ ); 2 - polluted site I (Prydniprovska Thermal Power Station, $n=6$ ); 3 - polluted site II (Zaporizhia, $n=6$ );

$$
* * *-\mathrm{P}<0.001
$$

The s-GFAP/c-GFAP in individuals caught near the Prydniprovska TPS increased by 5.1 times. The respective five times increase is characteristic for the snakes from Zaporizhia as well.

\section{Discussion}

Despite strong stability of intermediate filament structure in most eukaryotic cells, glial intermediate filaments represent a highly dynamic system, which is involved in a cellular response to various neural tissue 
injuries (Eng et al., 2000). The obtained data testify that industrial pollution induces considerable disturbances cytoskeleton structures of astrocytes in the reptile brain, which are considered as stable. The observed increase in c-GFAP testifies to intensive synthesis of GFAP and fibrillogenesis. Similar activation is characteristic for the induced astrogliosis, reactivation of astrocytes in response to action of adverse factors. Astrogliosis represents the adequate reactivation of the brain directed to support and protection of neurons and functional stability of the brain in general (Yang \& Wang, 2015). The main GFAP content, which is extracted with urea, presents in astrocytes as polymerized into filamentous insoluble cytoskeleton structures. Soluble fraction consists generally of subunits, which were synthesized in endoplasmic reticulum but have not been involved in direct polymerization to build intermediate filaments of cytoskeleton. After polymerization of soluble subunits into filamentous structures, the GFAP loses solubility and can be dissolved by the buffer with 4 $\mathrm{M}$ urea. The ratio of soluble and cytoskeletal fraction of GFAP is considered as an adequate molecular biomarker of the state of astrocytes' cytoskeleton (David et al., 1997; Eng et al., 2000; Nedzvetsky et al., 2012).

Differential estimation of soluble and insoluble filamentous forms of GFAP has a principal importance to characterize dynamic cytoskeleton plasticity, which promotes cell response against toxic factors including environment pollution. The recycling of soluble GFAP subunits is not completely understood; despite the fact that GFAP was first described as a soluble acidic protein derived from glial cells (Eng et al., 2000). After synthesis of soluble subunits, the intermediate filaments combine extremely quickly into cytoskeleton structure with no metabolic energy expenses (Aebi et al., 1988). Astrocytes affected by injuring factors lead to an increase of expression of intermediate filament proteins, which entails the dynamic reorganization of cytoskeleton. Required balance in cytoskeleton rearrangement could be followed by removal of separate subunits from the filamentous structure.

The considerable change manifested in the increase of soluble cytosolic fraction in comparison with the filamentous one affirms also the reduction of the s-GFAP subunit's polymerization rate. The rise of the number of soluble fragments testifies to the activation of the cytoskeleton reorganization with subsequent morphological changes in a cell. A similar process is accompanied by the relative decrease in the percentage of insoluble cytoskeleton proteins in the GFAP amount, as was revealed for the reptiles caught in the contaminated sites.

Based on obtained immunoblotting findings (Fig. 3, 5) we can conclude meaningful GFAP fragmentation into abundant fragments of 49 $35 \mathrm{kDa}$ molecular weight occurred for both s-GFAP and c-GFAP fractions. Characteristic increase in GFAP fragmentation is noted for the snakes from both studied polluted sites. Taking into account that every intermediate filamentous structure as well as its subunits is highly resistant to spontaneous dissociation, the obtained results attest to essential activation of proteolysis and consequent cytoskeletal reorganizations in the brain tissue of the dice snakes. The limited proteolysis could follow calpains' and caspases' cleavage that accompanies the cell abnormality (Gray et al., 2006; Chen et al., 2013). Besides, David et al. (1997) reported that increase in soluble GFAP content in the human brain is associated with a lack of brain functions. Furthermore, it was found that helper T cells released granzyme B upon contact with astrocytes and caused GFAP fragmentation (Stopnicki et al., 2019). Therefore, the GFAP fragmentation observed in our study could be recognized as an indicator of both astrocyte depletion and attenuation of brain functions in snakes affected by industrial contamination.

The growth of ROS level in the brain of snakes from both polluted sites was accompanied by the increase in GFAP fragmentation. The precise mechanisms of intermediate filaments' cleaving are not exactly understood yet. However, Smerjac et al. (2018) have recently demonstrated the carbonylation-induced proteosomal degradation of cytoskeleton proteins. Carbonylation is non-enzymatic modifying of proteins with aldehydes and/or ketones addition. This modification is one of primary consequences caused by oxidative stress and leads to the irreversible depletion of protein functioning (Miksík \& Deyl, 1997). Thus, the GFAP fragmentation detected in our study could be initiated with glial intermediate filaments carbonylation, which occurs as one of oxidative stress-induced abnormalities. On the other hand, astrocytes possess the ability to respond with reactivity against metabolic disturbances with subsequent adaptation to chronic toxicity (Bolanos, 2016).

Furthermore, the importance of GFAP fragments in the identification of human brain pathology has been studied recently (Zhang et al., 2014). As this takes place, the impact of GFAP fragmentation in the brain of ectothermic vertebrate animals caused by environmental toxicity remains unknown. However, allowing for our findings we can presume that industrial pollution could suppress astrocyte functions via upregulated GFAP fragmentation.

In spite of the large number of the studies concerning the role of GFAP in the brain of some vertebrate species, there is a limited number of the reports on the GFAP evaluation and its fragmentation in the reptilian brain under toxic effect of pollutants (Gasso et al., 2010, 2012). GFAP expression and glial intermediate filaments' rearrangement intimately relates to astrocytes and brain functioning (Eng et al., 2000). Dynamic GFAP turnover is critical to promote specific star-shaped morphology, cellular motility and astrocyte reactivity in response to different toxicity types. Moreover, GFAP is the main molecular biomarker of both astrocyte cytoskeleton state and its reactivity in the form of astrogliosis. Astrogliosis is confirmed as a phenomenon which occurs because of metabolic, regulatory, and structural disturbances caused by different stressful factors (Pekny et al., 2014). Astrogliosis is aimed mainly at localizing the damage and supporting the vitality of injured neurons.

Taking into account the fact that astrocytes are responsible for vital processes in the mammalian brain including support and repair of neuron injury, the obtained results evidence that snake astrocytes could exert a similar function against environmental toxicity (Nedzvetsky et al., 2006; Lohren et al., 2015). We studied the combined effect of real mixture and doses of industrial pollutants presented in natural river biotopes, and their capability to initiate neural cell disorders. Despite the distinct macroscopic structure and cytoarchitecture of reptilian glial cells in comparison with mammalian glia, the observed data support the hypothesis of the conservative evolutionary role of glial cells including the cellular response to exogenic toxicity (Miller \& O'Callaghan, 2003). Moreover, astrocytes of some reptiles exhibit similar biochemical and physiological properties to mammalian ones (Kálmán \& Pritz, 2001; Baydas et al., 2003).

Comparative analysis of GFAP expression in different species has shown its presence in major brain areas of fish, mammals and reptiles (Chiu, 1994; Nedzvetskii et al., 2001; Gasso et al., 2010; Malik, 2010; Kaas, 2016). Indeed, the representation and localization of astrocytes have class-specific features (Miller, 2018). Despite various astrocyte phenotypes, GFAP in all vertebrates is highly conservative in structure and the functions carried-out (Norenberg, 1994; Nedzvetsky et al., 2006; Tykhomyrov et al., 2008). Thus, the results obtained in our study evidence that reptilian neuroglia, as well as of other species, could play the vital role in support and ensuring of neurons' functioning through astrogliosis and GFAP upregulation. Local industrial pollution initiated the GFAP overexpression that could be supposed as a biomarker of the detrimental effect of environmental toxicity in snakes. Neuroglial cells are vital for maintenance of brain homeostasis because of protection against damage caused by different cytotoxic agents. As a rule, astrogliosis is accompanied by GFAP upregulation, extensive cytoskeleton rearrangement and astrocyte hypertrophy (Pekny et al., 2014; Hol \& Pekny, 2015). Astrocyte hypertrophy requires extensive fibrillogenesis, which is the main index of the reactive response to toxicity-induced brain injury. Furthermore, astrocytes have different receptors that promote its extremely high sensitivity and reactivity against multiple effects of toxicants (Sofroniew \& Vinters, 2010).

In our study, the observed ROS generation in the snakes' brain was accompanied by GFAP upregulation. Therefore, oxidative stress could be one of the stimulators of astrogliosis in the brain of snakes. Furthermore, comparative analysis has shown significant differences in both ROS level and GFAP content in the brain of animals inhabiting contaminated areas in comparison with snakes from the control one. Increased GFAP expression and upregulation under chronic exposure to local industrial contamination allow it to be used as a biomarker of industrial pollution.

Previous results demonstrated the association of oxidative stress level and astrogliosis activity in the rat's brain. However, the link between ROS level and astrogliosis in the brain of snakes exposed to industrial contaminants is presented here for the first time. 
Despite the limited data on glial cell biology in the reptilian brain, the observed results prove that snake astrocytes can respond to environmental toxicity using typical astroglial response. Summarizing the presented data, our findings evidence that GFAP expression and its fragmentation in the dice snakes are valid biomarkers of local industrial pollution.

\section{Conclusions}

Local industrial pollution induces oxidative stress and launches astrogliosis in the brain of snakes. GFAP upregulation in the course of astrogliosis is accompanied by increase in both soluble and insoluble (cytoskeleton, filamentous) fractions of GFAP, which reflects extensive cytoskeleton rearrangement. Therefore, the content of both soluble and insoluble GFAP forms in the dice snake brain, and its ratio could be recognized as valid biomarkers of local industrial pollution.

\section{References}

Aebi, U., Häner, M., Troncoso, J., Eichner, R., \& Engel, A. (1988). Unifying principles in intermediate filament (IF) structure and assembly. Protoplasma, 145(23), 73-81.

Barker, J. R., \& Tingey, D. T. (Eds). (1992). Air pollution effects on biodiversity. Springer US, New York.

Baxter, P. S., \& Hardingham, G. E. (2016). Adaptive regulation of the brain's antioxidant defences by neurons and astrocytes. Free Radical Biology and Medicine, $100,147-152$.

Baydas, G., Reiter, R. J., Nedzvetskii, V. S., Yaşar, A., Tuzcu, M., Ozveren, F., \& Canatan, H. (2003). Melatonin protects the central nervous system of rats against toluene-containing thinner intoxication by reducing reactive gliosis. Toxicology Letters, 137(3), 169-174

Block, M. L., \& Calderón-Garcidueñas, L. (2009). Air pollution: Mechanisms of neuroinflammation and CNS disease. Trends in Neurosciences, 32(9), 506-516.

Bolaños, J. P. (2016). Bioenergetics and redox adaptations of astrocytes to neuronal activity. Journal of Neurochemistry, 139(2), 115-125.

Bulakhov, V. L., Gasso, V. Y., \& Pakhomov, A. Y. (2007). Biolohichne riznomanittia Ukrainy. Dnipropetrovska oblast. Zemnovodni ta plazuny (Amphibia et Reptilia) [Biological Diversity of Ukraine. The Dnipropetrovsk region. Amphibians and Reptiles (Amphibia et Reptilia)]. Dnipropetrovsk National University, Dnipropetrovsk (in Ukrainian).

Cantonati, M., Poikane, S., Pringle, C. M., Stevens, L. E., Turak, E., Heino, J., Richardson, J. S., Bolpagni, R., Borrini, A., Cid, N., Ctvrtlíková, M., Galassi, D. M. P. Hájek, M., Hawes, I., Levkov, Z., Naselli-Flores, L., Saber, A. A., Di Cicco, M. Fiasca, B., Hamilton, P. B., Kubečka, J., Segadelli, S., \& Znachor, P. (2020). Characteristics, main impacts, and stewardship of natural and artificial freshwater environments: Consequences for biodiversity conservation. Water, 12(1), 260.

Chen, M. H., Hagemann, T. L., Quinlan, R. A., Messing, A., \& Perng, M. D. (2013). Caspase cleavage of GFAP produces an assembly-compromised proteolytic fragment that promotes filament aggregation. ASN Neuro, 5(5), e00125.

Chiu, S. Y., \& Kriegler, S. (1994). Neurotransmitter-mediated signaling between axons and glial cells. Glia, 11(2), 191-200.

Choban, A. F., \& Choban, S. Y. (2009). Otsinka vplyvu stichnyh vod TES na pryrodni vodni ob'ekty [Estimation of the impact of TPS sewage on natural water objects]. Ecology of the Environment and Safety of Life, 4, 52-58 (in Ukrainian).

Clements, W. H., \& Rohr, J. R. (2009). Community responses to contaminants: Using basic ecological principles to predict ecotoxicological effects. Environmental Toxicology and Chemistry, 28(9), 1789-1800.

David, J. P., Ghozali, F., Fallet-Bianco, C., Wattez, A., Delaine, S., Boniface, B. Di Menza, C., \& Delacourte, A. (1997). Glial reaction in the hippocampal formation is highly correlated with aging in human brain. Neuroscience Letters, 235(1-2), 53-56.

Eng, L. F., Ghirnikar, R. S., \& Lee, Y. L. (2000). Glial fibrillary acidic protein: GFAP-thirty-one years (1969-2000). Neurochemical Research, 25(9-10), $1439-1451$.

Gasso, V. Y. (2011). Kharakterystyka populiatsii zvychainoho vuzha lisovykh bioheotsenoziv Prysamaria [Grass snake populations' features of the forest biogeocoenoses in the Samara river area]. Visnyk of Dnipropetrovsk University, Biology, Ecology, 19(2), 136-142 (in Ukrainian).

Gasso, V. Y., Hahut, A. M., \& Yermolenko, S. V. (2016). Biokhimichni pokaznyky krovi zvychainoho vuzha (Natrix natrix) z ekosystem iz riznym stupenem antropohennoho navantazhennia [Biochemical parameters in the blood of grass snakes (Natrix natrix) in ecosystems under varying degrees of anthropogenic influence]. Visnyk of Dnipropetrovsk University, Biology, Medicine, 7(2), 127131 (in Ukrainian).

Gasso, V. Y., Klymenko, E. Y., \& Nedzvetsky, V. S. (2010). Sostoianie cytoskeletnyh molekuliamyh komponentov mozga prytkoj yashcheritsy kak biomarker narushenij, indutsyrovannyh promyshlennym zagriazneniem [Cytoskeleton molecular components of the sand lizard's brain as a biomarker of disorders induced by industrial pollution]. Ecology and Noospherology, 21(1-2), 98-104 (in Russian).

Gasso, V. Y., Klymenko, O. Y., Sukharenko, H. V., \& Nedzvetsky, V. S. (2012). Otsenka negativnogo effekta zagriazneniia biogeocenozov s ispol'zovaniem neirospetsificheskogo cytoskeletnogo belka prytkoj yashcheritsy [Assessment of negative effect of the biogeocoenoses pollution with the use of neurospecific cytoskeletal protein of the sand lizard]. Ecology and Noospherology, 23, 58-66 (in Russian).

Gray, B. C., Skipp, P., O’Connor, V. M., \& Perry, V. H. (2006). Increased expression of glial fibrillary acidic protein fragments and mu-calpain activation within the hippocampus of prion-infected mice. Biochemical Society Transactions, 34 $51-54$.

Gupta, D., Crosby, M. E., Almasan, A., \& Macklis, R. M. (2008). Regulation of CD20 expression by radiation-induced changes in intracellular redox status. Free Radical Biology and Medicine, 44(4), 614-623.

Hall, Z. J., \& Tropepe, V. (2020). Using teleost fish to discern developmental signatures of evolutionary adaptation from phenotypic plasticity in brain structure. Frontiers in Neuroanatomy, 14, 10

Hol, E. M., \& Pekny, M. (2015). Glial fibrillary acidic protein (GFAP) and the astrocyte intermediate filament system in diseases of the central nervous system. Current Opinion in Cell Biology, 32, 121-130.

Kaas, J. H. (2016). Evolution of nervous systems. Academic Press, Cambridge.

Kálmán, M., \& Pritz, M. B. (2001). Glial fibrillary acidic protein-immunopositive structures in the brain of a Crocodilian, Caiman crocodilus, and its bearing on the evolution of astroglia. Journal of Comparative Neurology, 431(4), 460-480.

Kálmán, M., \& Szabó, A. (2001). Immunohistochemical investigation of actinanchoring proteins vinculin, talin and paxillin in rat brain following lesion: A moderate reaction, confined to the astroglia of brain tracts. Experimental Brain Research, 139(4), 426-434

Kendall, R. J. (2016). Wildlife toxicology: Where we have been and where we are going, Journal of Environmental and Analytical Toxicology, 6(1), 348.

Kim, H. Y., Kim, H. R., Kang, M. G., Trang, N. T. D., Baek, H. J., Moon, J. D., Shin, J.-H., Suh, S.-P., Ryang, D.-W., Kook, H., \& Shin, M. G. (2014). Profiling of biomarkers for the exposure of polycyclic aromatic hydrocarbons: lamin-A/C isoform 3, poly[ADP-ribose] polymerase 1 , and mitochondria copy number are identified as universal biomarkers. Biomed Research International, 2014,605135 .

Kirici, M., Nedzvetsky, V. S., Agca, C. A., \& Gasso, V. Y. (2019). Sublethal doses of copper sulphate initiate deregulation of glial cytoskeleton, NF-kB and PARP expression in Capoeta umbla brain tissue. Regulatory Mechanisms in Biosystems, 10(1), 103-110.

Klymenko, O. Y., \& Gasso, V. Y. (2009). Aktyvnist transaminaz u syrovattsi krovi prudkoi yashchirky pid vplyvom promyslovoho zabrudnennia [Transaminases activity in the sand lizard's serum under influence of industrial pollution]. Visnyk of Dnipropetrovsk University, Biology, Ecology, 17(1), 100-105 (in Ukrainian)

Kroik, H. A., \& Patskova, Y. L. (2011). Otsinka ekolohichnoho stanu pryrodnykh vod v zoni diyi Prydniprovskoyi TES [Estimation of the ecological state of natural waters in the zone of operation of Prydniprovska TPS]. Visnyk of Dnipropetrovsk University, Geology, Geography, 13(1), 53-61 (in Ukrainian).

Laemmli, U. K. (1970). Cleavage of structural proteins during the assembly of the head of bacteriophage T4. Nature, 227(5259), 680-685.

Legradi, J. B., Di Paolo, C., Kraak, M. H. S., Van der Geest, H. G., Schymanski, E. L., Williams, A. J., Dingemans, M. M. L., Massei, R., Brack, W., Cousin, X., Begout, M.-L., Van der Oost, R., Carion, A., Suarez-Ulloa, V., Silvestre, F., Escher, B. I., Engwall, M., Nilén, G., Keiter, S. H., Pollet, D., Waldmann, P., Kienle, C., Werner, I., Haigis, A.-C., Knapen, D., Vergauwen, L., Spehr, M., Schulz, W., Busch, W., Leuthold, D., Scholz, S., Vom Berg, C. M., Basu, N., Murphy, C. A., Lampert, A., Kuckelkom, J., Grummt, T., \& Hollert, H. (2018). An ecotoxicological view on neurotoxicity assessment. Environmental Sciences Europe, 30(1), 46

Lieshchova, M. A., Tishkina, N. M., Bohomaz, A. A., Gavrilin, P. M., \& Brygadyrenko, V. V. (2018). Combined effect of glyphosphate, saccharin and sodium benzoate on rats. Regulatory Mechanisms in Biosystems, 9(4), 591-597.

Lieshchova, M. A., Brygadyrenko, V. V., Tishkina, N. M., Gavrilin, P. M., \& Bohomaz, A. A. (2019). Impact of polyvinyl chloride, polystyrene, and polyethylene on the organism of mice. Regulatory Mechanisms in Biosystems, $10(1), 50-55$.

Lohren, H., Blagojevic, L., Fitkau, R., Ebert, F., Schildknecht, S., Leist, M., \& Schwerdtle, T. (2015). Toxicity of organic and inorganic mercury species in differentiated human neurons and human astrocytes. Journal of Trace Elements in Medicine and Biology, 32, 200-208

Lorincz, D., \& Kálmán, M. (2015). Advances of Squamata astroglia to other reptiles: Numerous astrocytes and glial fibrillary acidic protein (GFAP)-free areas. A preliminary study. Acta Biologica Szegediensis, 59(3), 353-360. 
Lucchini, R. G., Dorman, D. C., Elder, A., \& Veronesi, B. (2012). Neurological impacts from inhalation of pollutants and the nose-brain connection. Neurotoxicology, 33(4), 838-841.

Malik, M. G. (2010). Vykorystannia hlialnoho fibryliamoho kysloho bilka mozku ryb u diahnostytsi stanu pryrodnoho seredovyshcha [Use of glial fibrillary acidic protein extracted from the fish brain in diagnostics of the environment state]. Visnyk of Dnipropetrovsk University, Biology, Ecology, 18(1), 92-97 (in Ukrainian).

Miksík, I., \& Deyl, Z. (1997). Post-translational non-enzymatic modification of proteins. II. Separation of selected protein species after glycation and other carbonyl-mediated modifications. Journal of Chromatography B: Biomedical Sciences and Applications, 699, 311-345.

Miller, D. B., \& O’Callaghan, J. P. (2003). Elevated environmental temperature and methamphetamine neurotoxicity. Environmental Research, 92(1), 48-53.

Miller, G. L. (1959). Protein determination of large numbers of samples. Analytical Chemistry, 31(5), 964-964.

Miller, S. J. (2018). Astrocyte heterogeneity in the adult central nervous system. Frontiers in Cellular Neuroscience, 12, 401

Nedzvetskii, V. S., Nerush, P. A., Tikhomirov, A. A., \& Romanenko, L. A. (2001) Effects of ionizing radiation and aluminum chloride on protein of glial intermediate filaments in the rat brain. Neurophysiology, 33, 28-33.

Nedzvetskii, V. S., Tykhomyrov, A. O., Kirichenko, S. V., Koryakina, Z. O., \& Lipka, M. V. (2005). Vozmozhnosti ispol'zovaniia molekuliarnyh komponentov s tsel'iu sohraneniia biologicheskogo raznoobraziia $\mathrm{V}$ usloviiah deistviia neblagopriiatnyh faktorov [The possibilities of use of molecular components to protect biodiversity under influence of harmful factors]. Ecology and Noospherology, 16(3-4), 215-221 (in Russian).

Nedzvetsky, V. S., \& Nerush, P. A. (1999). The protein of glial intermediate filaments in different areas of the rat brain at experimental neurosis. Neurophysiology, 31(2), $94-97$.

Nedzvetsky, V. S., Sukharenko, E. V., Kyrychenko, S. V., \& Baydas, G. (2018). Soluble curcumin prevents cadmium cytotoxicity in primary rat astrocytes by improving a lack of GFAP and glucose-6-phosphate-dehydrogenase. Regulatory Mechanisms in Biosystems, 9(4), 501-507.

Nedzvetsky, V. S., Sukharenko, E. V., \& Nerush, O. P. (2011). Biologicheskaya i sotsialnaya znachimost ispolzovaniya molekulyarnykh komponentov s tselyu opredeleniya metabolicheskikh narusheniy, vyzvannykh ionami alyuminiya [Biological and social importance of molecular marker investigation for determination of metabolic disease induced by aluminum ions]. Scientific Notes of the Russian State Social University, 92, 192-196 (in Russian)

Nedzvetsky, V. S., Tuzcu, M., Yasar, A., Tikhomirov, A. A., \& Baydas, G. (2006). Effects of vitamin $\mathrm{E}$ against aluminum neurotoxicity in rats. Biochemistry, 71(3), 239-244.

Newman, M. C., \& Clements, W. H. (2007). Ecotoxicology: A comprehensive treatment. CRC Press, Boca Raton.

Norenberg, M. D. (1994). Astrocyte responses to CNS injury. Journal of Neuropathology and Experimental Neurology, 53(3), 213-220.

Novitsky, R. A., Malik, M. G., Nedzvetsky, V. S., \& Sukharenko, E. V. (2009). Ispolzovaniye tsitoskeletnykh molekulyarnykh komponentov $\mathrm{v}$ kachestve biomarkera sostoyaniya gidrobiontov (na primere plotvy obyknovennoy) [Use of cytoskeletal molecular components as biomarker of the hydrobionts state (using common roach as an example)]. Hydrobiological Journal, 45(5), 81-88 (in Russian).

Novitsky, R. A., Sukharenko, E. V., \& Nedzvetsky, V. S. (2013). Molekuliarnye biomarkery effektov ionov $\mathrm{Al}^{3+}$ na generaciju oksidativnogo stressa i kletochnuiu reaktivaciiu v organizme Lepomis gibbosus (Pisces: Centrarchidae) [Molecular biomarkers of the effects of $\mathrm{Al}^{3+}$ ions on oxidative stress generation and cell reactivation in Lepomis gibbosus (Pisces: Centrarchidae)]. Hydrobiological Journal, 49(6), 65-75 (in Russian).

Ortega, A., \& Olivares-Bañuelos, T. N. (2020). Neurons and glia cells in marine invertebrates: An update. Frontiers in Neuroscience, 14, 121.

Peakall, D. B., Walker, C. H., \& Migula, P. (1999). Biomarkers: A pragmatic basis for remediation of severe pollution in Eastern Europe. Springer, Berlin.

Pekny, M., Wilhelmsson, U., \& Pekna, M. (2014). The dual role of astrocyte activation and reactive gliosis. Neuroscience Letters, 565, 30-38.

Pereira, P., Korbas, M., Pereira, V., Cappello, T., Maisano, M., Canário, J., Almeida, A., \& Pacheco, M. (2019). A multidimensional concept for mercury neuronal and sensory toxicity in fish - From toxicokinetics and biochemistry to morphometry and behavior. Biochimica et Biophysica Acta (BBA) - General Subjects, 1863(12), 129298.

Peters, A., Palay, S. L., \& Webster, H. de F. (1991). The fine structure of the nervous system: Neurons and their supporting cells. Oxford University Press, New York.

Peterson, E. K., Buchwalter, D. B., Kerby, J. L., Le Fauve, M. K., Varian-Ramos, C. W., \& Swaddle, J. P. (2017). Integrative behavioral ecotoxicology: Bringing together fields to establish new insight to behavioral ecology, toxicology, and conservation. Current Zoology, 63(2), 185-194.

Prychynenko, N. M., Hurkova, O. O., Rozovenko, I. V., Kompaniiets, A. V., Voloshyna, O. M., \& Shvachko, O. O. (2017). Rehionalna dopovid pro stan navkolyshnoho pryrodnoho seredovyshcha u Zaporizskii oblasti u 2016 rotsi [Regional report on the state of the environment in Zaporizhia region in 2016] Zaporizska Oblast State Administration, Zaporizhia (in Ukrainian).

Rai, A., Maurya, S. K., Sharma, R., \& Ali, S. (2013). Down-regulated GFAP A major player in heavy metal induced astrocyte damage. Toxicology Mechanisms and Methods, 23(2), 99-107.

Rueden, C. T., Schindelin, J., Hiner, M. C., DeZonia, B. E., Walter, A. E., Arena, E. T., \& Eliceiri, K. W. (2017). ImageJ2: ImageJ for the next generation of scientific image data. BMC Bioinformatics, 18(1), 529.

Sanderfoot, O. V., \& Holloway, T. (2017). Air pollution impacts on avian species via inhalation exposure and associated outcomes. Environmental Research Letters, 12(8), 083002

Schäfer, R. B., \& Bundschuh, M. (2018), Ecotoxicology. In: Schmutz, S., \& Sendzimir, J. (Eds). Riverine ecosystem management. Aquatic Ecology Series. Springer, Cham. Vol. 8. Pp. 225-239.

Schneider, C. A., Rasband, W. S., \& Eliceiri, K. W. (2012). NIH Image to ImageJ: 25 years of image analysis. Nature Methods, $9(7), 671-675$

Smerjac, S. M., Zheng, J., Hu, C. L., \& Bizzozero, O. A. (2018). The role of calpain and proteasomes in the degradation of carbonylated neuronal cytoskeletal proteins in acute experimental autoimmune encephalomyelitis. Neurochemical Research, 43(12), 2277-2287.

Sofroniew, M. V., \& Vinters, H. V. (2010). Astrocytes: Biology and pathology. Acta Neuropathologica, 119(1), 7-35.

Stopnicki, B., Blain, M., Cui, Q. L., Kennedy, T. E., Antel, J. P., Healy, L. M., \& Darlington, P J. (2019). Helper CD4 T cells expressing granzyme B cause glial fibrillary acidic protein fragmentation in astrocytes in an MHCII-independent manner. Glia, 67(4), 582-593.

Strilets, R. O. (Ed.) (2017). Rehionalna dopovid pro stan navkolyshnoho pryrodnoho seredovyshcha v Dnipropetrovskii oblasti za 2016 rik [Regional report on the state of the environment in Dnipropetrovsk region in 2016]. Dnipropetrovska Oblast State Administration, Dnipro (in Ukrainian).

Sukharenko, E. V., Samoylova, I. V., \& Nedzvetsky, V. S. (2017). Molecular mechanisms of aluminium ions neurotoxicity in brain cells of fish from various pelagic areas. Regulatory Mechanisms in Biosystems, 8(3), 461-466.

Sukharenko, E. V., Novitsky, R. A., \& Nedzvetsky, V. S. (2012). Vykorystannia biomarkeriv mozku donnykh ryb dlia otsinky zabrudnennia kerchensko protoky Chornoho moria [Using biomarkers of ground fish brain for pollution assessment of the Kerch strait (the Black Sea)]. Visnyk of Dnipropetrovsk University, Biology, Medicine, 3(2), 81-88 (in Ukrainian).

Tanaka, K. I., \& Kawahara, M. (2017). Copper enhances zinc-induced neurotoxicity and the endoplasmic reticulum stress response in a neuronal model of vascular dementia. Frontiers in Neuroscience, 11, 58.

Taysi, M. R., Söğüt, B., Nedzvetsky, V. S., Kirici, M., \& Ağca, C. A. (2019). Sublethal doses of inorganic mercury induce dose-depended upregulation of RPA1 content and inhibit p53 expression in the brain of rainbow trout (Oncorhynchus mykiss). Türk Tarım ve Doğa Bilimleri Dergisi, 6(3), 462-476.

Tykhomyrov, A. A., Nedzvetsky, V. S., Klochkov, V. K., \& Andrievsky, G. V. (2008). Nanostructures of hydrated $\mathrm{C}_{60}$ fullerene $\left(\mathrm{C}_{60} \mathrm{HyFn}\right)$ protect rat brain against alcohol impact and attenuate behavioral impairments of alcoholized animals. Toxicology, 246(2-3), 158-165.

Van de Perre, D., Roessink, I., Janssen, C. R., Smolders, E., Van Regenmortel, T., Van Wichelen J., Vyverman, W., Van den Brink, P. J., \& De Schamphelaere, K. A. C. (2016). The effects of zinc on the structure and functioning of a freshwater community: A microcosm experiment. Environmental Toxicology, 35(11), 2698-2712

Yang, Z., \& Wang, K. K. (2015). Glial fibrillary acidic protein: From intermediate filament assembly and gliosis to neurobiomarker. Trends in Neurosciences, 38(6), 364-374.

Yermolenko, S. V., Hagut, A. M., \& Gasso, V. Y. (2016a). Morphophysiological indices of internal organs of the dice snake Natrix tessellata (Reptilia, Colubridae) of the Dnieper River in the steppe. Zbimyk Prac Zoologichnogo Muzeju, 47, 20-29.

Yermolenko, S. V., Hahut, A. M., \& Gasso, V. Y. (2016b). Izmenchivost morfometricheskih priznakov vodianogo uzha Natrix tessellata (Reptilia, Colubridae) Tsentral'nogo i Yuzhnogo Pridneprov'ia [Variation in morphological characters of the dice snake Natrix tessellata (Reptilia, Colubridae) in the Central and Southern Dnieper River Area]. Visnyk of Dnipropetrovsk University, Biology, Ecology, 24(2), 526-530 (in Russian).

Yoshikawa, T., \& Naito, Y. (2002). What is oxidative stress? Japan Medical Association Journal, 45(7), 271-276

Zhang, Z., Zoltewicz, J. S., Mondello, S., Newsom, K. J., Yang, Z., Yang, B., Kobeissy, F., Guingab, J., Glushakova, O., Robicsek, S., Heaton, S., Buki, A., Hannay, J., Gold, M. S., Rubenstein, R., Lu, X. C., Dave, J. R., Schmid, K., Tortella, F., Robertson, C. S., \& Wang, K. K. (2014). Human traumatic brain injury induces autoantibody response against glial fibrillary acidic protein and its breakdown products. PLoS One, 9(3), e92698. 